\title{
De codificatie van gedragsnormen in het Nederlands rechtspersonenrecht: een gewenste ontwikkeling?
}

\author{
L. Thomae LLM en H. Koster $L L M^{*}$
}

\begin{abstract}
In deze bijdrage beantwoorden de auteurs de vraag of het wenselijk is om de (algemene) gedragsnormen die onder meer voortvloeien uit de jurisprudentie in Boek $2 \mathrm{BW}$ te codificeren. Voor de beantwoording van deze vraag zullen onder meer de gedragsnormen uit de Companies Act 2006 aan de orde komen.
\end{abstract}

\section{Inleiding}

In deze bijdrage richten wij ons op de gedragsnormen die gelden voor de namens de rechtspersoon handelende bestuur$\operatorname{der}(s) .{ }^{1}$ Deze gedragsnormen kunnen naar huidig recht vooral worden afgeleid uit de jurisprudentie over bestuurdersaansprakelijkheid. Het bestuurdersaansprakelijkheidsrecht heeft in Nederland een belangrijke normerende functie in het maatschappelijke leven: het dwingt bestuurders zich te houden aan de geldende maatschappelijke gedragsnormen. $\mathrm{Nu}$ rijst de vraag wat deze gedragsnormen zijn en wanneer sprake is van een normschending. Het Nederlands rechtspersonenrecht kent diverse gedragsnormen die zich richten tot de bestuurder en die hem voorhouden welke gedragslijn van hem wordt verwacht. $^{2}$ Zo bepaalt artikel 2:9 van het Burgerlijk Wetboek (BW) dat iedere bestuurder tegenover de rechtspersoon verplicht is tot een 'behoorlijke taakvervulling' van de hem opgedragen taak. Dergelijke gedragsnormen zijn open van aard: de concrete invulling is in de meeste gevallen contextafhankelijk. ${ }^{3}$ Om duidelijkheid te krijgen over de concrete invulling van de gedragsnormen moet worden gekeken naar de omvangrijke en soms enigszins onduidelijke jurisprudentie over dit onder-

* L. Thomae LLM is student International Management aan de Radboud Universiteit. H. Koster LLM is verbonden aan de Erasmus School of Law en aan de Universiteit van Dubai.

1. In deze bijdrage gaan wij uit van normen die voor alle Boek 2 BW-rechtspersonen gelden. Wij menen dat met algemene gedragsnormen die voor alle Boek 2 BW-rechtspersonen gelden voldoende recht kan worden gedaan aan de verscheidenheid van Boek 2 BW-rechtspersonen. Zie hierover echter ook J.B. Huizink, Bestuur en toezicht bij rechtspersonen, mede in de semipublieke en non-profitsector (Preadvies van de Vereeniging 'Handelsrecht'), Zutphen: Uitgeverij Paris 2016, p. 29.

2. B.F. Assink \& J.M. de Jongh, Gedragsnormen, enquêterecht en aandeelhouder, in: B.F. Assink e.a. (red.), De toekomst van het ondernemingsrecht (IVOR nr. 99), Deventer: Wolters Kluwer 2015, p. 2.

3. W. Khan, Towards context-specific directors duties and enforcement mechanisms in the banking sector?, Erasmus Law Review 2013, afl. 2, p. 95-96; Assink \& De Jongh 2015, p. 2. werp. Deze open gedragsnormen kunnen tot onzekerheid en onduidelijkheid bij bestuurders van rechtspersonen leiden. Dit kan - zoals Kroeze dat in 2005 noemde - tot 'bange bestuurders' leiden. Hierdoor kunnen bestuurders afzien van risicovolle, maar potentieel winstgevende beslissingen en eerder kiezen voor een veiligere, maar wellicht minder winstgevende weg. Dit ten nadele van de Nederlandse economische groei. ${ }^{4}$ Om deze onzekerheid te reduceren is het daarom van belang duidelijkheid te verschaffen over de vraag wanneer een bestuurder aansprakelijk is voor zijn gedrag. Een codificatie van de geldende rechtspraak in duidelijk geformuleerde gedragsnormen kan hier mogelijk bij helpen.

Ook in het Verenigd Koninkrijk was, tot invoering van de Companies Act 2006 (hierna: CA 2006), het leerstuk van bestuurdersaansprakelijkheid voornamelijk gebaseerd op de rechtspraak. Hierdoor bestond de nodige onduidelijkheid over de vraag aan welke plichten bestuurders precies onderworpen waren. ${ }^{5}$ De rechtspraak over de gedragsnormen voor bestuurders was in de loop van de tijd erg complex geworden. Ook waren de plichten van bestuurders zeer gefragmenteerd opgenomen in diverse rechterlijke uitspraken. Om deze onduidelijkheid weg te nemen zijn in de CA 2006 de gedragsnormen (grotendeels) gecodificeerd. Het belangrijkste doel dat met deze codificatie werd nagestreefd, was het vereenvoudigen en verduidelijken van de plichten die bestuurders jegens de rechtspersoon hebben. Hiertoe bevat de CA 2006 nu een zevental algemene plichten die bestuurders steeds in acht dienen te nemen bij het nemen van besluiten. Deze plichten zijn vastgelegd in de artikelen $171 \mathrm{t} / \mathrm{m} 177$ CA 2006. Deze omvatten enerzijds de fiduciaire plichten van bestuurders en anderzijds de plicht om te handelen met redelijke vaardigheid, toezicht en zorgvuldigheid. ${ }^{6}$

4. M.J. Kroeze, Bange bestuurders, Ondernemingsrecht 2006, afl. 3, par. 6.

5. A. Hicks \& S.H. Goo, Cases \& materials on company law, Oxford: Oxford University Press 2008, p. 356; L. Sealy \& S. Worthington, Cases and materials in company law, Oxford: Oxford University Press 2007, p. 273-274.

6. P.L. Davies, L.C.B. Gower, S. Worthington \& E. Micheler, Gower's principles of modern company law, Londen: Sweet \& Maxwell 2016, p. 486. 


\section{Maandblad}

Ondernemingsrecht

In deze bijdrage beantwoorden wij de vraag of het wenselijk is om de (algemene) gedragsnormen die onder meer voortvloeien uit de jurisprudentie in Boek 2 BW te codificeren. Voor de beantwoording van deze vraag wordt allereerst kort ingegaan op de algemene regels over bestuurdersaansprakelijkheid in Nederland en welke algemene gedragsnormen er in Nederland reeds worden onderscheiden (par 2). Vervolgens komen de gedragsnormen uit de CA 2006 aan de orde (par. 3), waarna wordt gekeken of in Nederland ook dergelijke gedragsnormen gelden (par. 4). Ten slotte wordt in paragraaf 5 de vraag beantwoord of codificatie van deze gedragsnormen in Boek 2 BW wenselijk is.

\section{Gedragsnormen in de context van bestuurdersaansprakelijkheid}

In Staleman/Van de Ven heeft de Hoge Raad beslist dat een bestuurder aansprakelijk is op grond van artikel 2:9 BW indien hem een ernstig verwijt van onbehoorlijk bestuur kan worden gemaakt. ${ }^{7}$ Of in een bepaald geval sprake is van ernstig verwijt, moet worden beoordeeld aan de hand van alle omstandigheden van het geval. Maatgevend hierbij is het inzicht en de zorgvuldigheid die mogen worden verwacht van een bestuurder die voor zijn taak is berekend en deze nauwgezet vervult. ${ }^{8}$ In de literatuur worden de verplichtingen die een bestuurder heeft op grond van artikel 2:9 BW wel onderverdeeld in een plicht tot loyaal handelen (duty of loyalty) en een plicht tot zorgvuldig handelen (duty of care). ${ }^{9}$ De loyaliteitsplicht houdt in dat een bestuurder zijn taakopdracht jegens de rechtspersoon over de volle breedte naar eer en geweten dient te vervullen op een daadwerkelijk integere wijze. ${ }^{10}$ Uit deze loyaliteitsplicht vloeit onder andere voort dat het bestuurders niet is toegestaan om voor privédoeleinden een ondernemingskans van de rechtspersoon over te nemen. De plicht tot zorgvuldig handelen houdt in dat bestuurders hun taak op een objectief zorgvuldige wijze moeten vervullen. Hierbij dient te worden voldaan aan diverse maatschappelijke en (on)geschreven normen. Aan deze twee algemene verplichtingen voor bestuurders zijn nog diverse andere verplichtingen verbonden, zoals de tegenstrijdig-belangbepalingen.

Daarnaast kan in geval van faillissement van een rechtspersoon de curator, namens de boedel, iedere bestuurder aansprakelijk stellen voor het tekort. Dit kan indien het bestuur zijn taak kennelijk onbehoorlijk heeft vervuld en aannemelijk is dat dit

7. HR 10 januari 1997, ECLI:NL:HR:1997:ZC2243

8. Zie ook HR 4 april 2003, ECLI:NL:HR:2003:AF3419 (Skipper), HR 29 november 2002, ECLI:NL:HR:2002:AE7011 (Schwandt/Berghuizer Papierfabriek) en HR 20 juni 2008, ECLI:NL:HR:2008:BC4959 (Willemsen/NOM).

9. Zie bijv. M.L. Lennarts, Aansprakelijkheid van bestuurders en toezichthouders bij stichtingen, in: De stichting; kritische beschouwing over de wettelijke regeling voor een veelzijdige rechtsvorm, Den Haag: Sdu Uitgevers 2011, p. 135-152; B.F. Assink, Rechterlijke toetsing van bestuurlijk gedrag (IVOR nr. 59), Deventer: Kluwer 2007, p. 509 e.v.

10. Assink/Slagter, Compendium ondernemingsrecht, Deventer: Kluwer $2013, \$ 51$. een belangrijke oorzaak van het faillissement is. ${ }^{11}$ In het Panmo-arrest heeft de Hoge Raad overwogen dat sprake is van kennelijk onbehoorlijk bestuur indien geen redelijk denkende bestuurder onder dezelfde omstandigheden zo zou hebben gehandeld. ${ }^{12}$ Ook hierbij moet worden gekeken naar alle omstandigheden van het geval. ${ }^{13}$ Ten slotte kan een bestuurder door een derde persoonlijk aansprakelijk worden gesteld op grond van een onrechtmatige daad. Hiervoor is vereist dat de bestuurder persoonlijk een 'voldoende ernstig persoonlijk verwijt' te maken moet zijn. ${ }^{14}$ De conclusie is dat deze gedragsnormen open van aard zijn. De concrete invulling is in de kern contextafhankelijk.

\section{Verenigd Koninkrijk: the general duties of directors}

Zoals in de inleiding aangeduid, bevat de CA 2006 een gedeeltelijke codificatie van de rechtspraak over directors' duties. Deze wettelijke regeling bevat niet alle plichten van een bestuurder; sommige plichten zijn elders in de wetgeving opgenomen. ${ }^{15}$ Het doel van deze codificatie was enerzijds het verschaffen van duidelijkheid over de gedragsnormen van bestuurders en anderzijds om de ontwikkeling van de wet voorspelbaarder te maken. ${ }^{16}$ Kanttekening hierbij is dat de jurisprudentie over de plichten voor bestuurders van voor de codificatie van belang is gebleven; ${ }^{17}$ de wettelijke plichten moeten geïnterpreteerd worden in het licht van de bestaande rechtspraak en de common law. ${ }^{18}$ Daarnaast is common law van belang gebleven voor de vraag welke consequenties een inbreuk op een plicht heeft. ${ }^{19}$ De algemene plichten in de CA 2006 (art. 171-177) zullen hieronder worden besproken.

\subsection{Duty to act within powers (art. 171)}

Op grond van artikel 171 CA 2006 dient een bestuurder binnen zijn bevoegdheden te handelen. Dit houdt in dat een bestuurder moet handelen conform de statuten en dat een bestuurder zijn bevoegdheden enkel gebruikt voor het doel waarvoor zij bedoeld zijn. Dit laatste kan ook worden aange-

11. In de rechtsliteratuur bestaat onenigheid over de vraag of ernstig verwijtbaar handelen van de bestuurder een grond is om kennelijk onbehoorlijk bestuur aan te nemen. Wij menen dat deze maatstaf niet wezenlijk verschilt van de ernstig-verwijtmaatstaf van art. 2:9 BW. Zo ook Asser/ Maeijer \& Kroeze 2-I* 2015/208. Anders: Assink/Slagter 2013, \$51.

12. HR 8 juni 2001, ECLI:NL:HR:2001:AB2053 (Panmo).

13. HR 14 oktober 2005, ECLI:NL:HR:2005:AT6017 (Holland Foodmachinery).

14. HR 18 januari 2000, ECLI:NL:HR:2000:AA4873 (New Holland Belgium/Oosterhof); HR 2 maart 2007 ECLI:NL:HR:2007:AZ3535 (Nutsbedrijf Westland); HR 11 september 2009, ECLI:NL:HR: 2009:BH4033 (Comsys/Van den End q.q.); HR 20 juni 2008, ECLI:NL:HR:2008:BC4959(Willemsen Beheer/NOM).

15. Zoals bijv. de plicht om de boekhouding te voeren en de plicht om de gezondheid en veiligheid van de werknemers te beschermen. Zie hierover M. Bruce, Rights and duties of directors, Londen: Bloomsbury Professional 2016, p. 67.

16. T. Ashraf, Directors' duties with a particular focus on the Companies Act 2006, International Journal of Law \& Management (54) 2012, afl. 2, p. 125-140.

17. Davies e.a. 2016, p. 486.

18. Art. 170 (4) CA 2006.

19. Art. 178 CA 2006. 
duid als het verbod op détournement de pouvoir. Dit houdt onder andere in dat een bestuurder zijn bevoegdheden moet gebruiken om de doelstellingen van de rechtspersoon te bereiken, en niet zijn eigen doelen. ${ }^{20}$

\subsection{Duty to promote the success of the company (art. 172)}

De tweede gedragsnorm voor bestuurders in de CA 2006 stelt dat het de plicht van een bestuurder is om het succes van het bedrijf te bevorderen ten behoeve van zijn aandeelhouders als geheel. ${ }^{21}$ Dit wordt wel aangeduid als de kernplicht waaraan bestuurders onderworpen zijn, omdat deze plicht van toepassing is op alle besluiten van een bestuurder. ${ }^{22}$ Lord Goldsmith omschreef 'succes' als:

'success means what the members collectively want the company to achieve. For a commercial company, success will usually mean long-term increase in value. ${ }^{23}$

Op grond van artikel 172 CA 2006 moet een bestuurder bij het nemen van besluiten onder andere rekening houden met (a) de consequenties van een besluit op de lange termijn, (b) de werknemersbelangen, (c) de noodzaak om de relaties met klanten, leveranciers en anderen te bevorderen, (d) de invloed van de activiteiten van de rechtspersoon op de samenleving en het milieu, (e) de wens van de rechtspersoon om een 'reputation for high standards of business conduct' te behouden, en (f) de noodzaak om de onderscheiden aandeelhouders onderling fair te behandelen. ${ }^{24}$ Dit wordt ook wel als de 'enlightened shareholder value'-benadering aangemerkt. Er geldt een verplichting om met andere belangen dan die van aandeelhouders rekening te houden, maar die andere belangen hebben in beginsel minder zelfstandige betekenis dan het aandeelhoudersbelang. Als evenwel bijvoorbeeld de rechtspersoon in financiële problemen raakt, kan het crediteurenbelang voorgaan. De weging van de belangen is daarmee afhankelijk van de context. Een voordeel van deze benadering is dat het bestuurders, meer dan in de huidige vrije Nederlandse benadering, dwingt om toe te lichten waarom zij tot een bepaalde belangenafweging zijn gekomen. De rechter constateert evenwel slechts tot strijd met artikel 172 CA 2006 als met betrekking tot het besluit geldt dat 'no reasonable director could have considered it to be in the company's best interest'. ${ }^{25}$

20. Ashraf 2012; Davies e.a. 2016, p. 487-494

21. Op deze duty is overigens veel kritiek geleverd, zowel tijdens de parlementaire behandeling van het wetsvoorstel als daarna. Zie hierover G. Tsagas, Section 172 of the UK Companies Act 2006: Desperate times call for soft law measures, Oxford Business Law Blog, 1 september 2017.

22. Davies e.a. 2016, p. 501.

23. Lords Grand Committee, 6 februari 2006, column 255.

24. Deze factoren zijn niet limitatief. Zie ook A. Dignam \& J. Lowry, Company law, Oxford: Oxford University Press 2010, p. 328.

25. Cobden Investments Ltd. v RWM Langport Ltd. [2008] EWHC 2810 (Ch). Zie ook E. Lim, Judicial intervention in director's decision-making process: Section 172 of the Companies Act, Journal of Business Law $2018 / 169$

\subsection{Duty to exercise independent judgment (art. 173)}

De derde gedragsnorm ziet toe op de verplichting van een bestuurder om onafhankelijke oordeelsvorming in acht te nemen. ${ }^{26}$ Dit houdt in dat een bestuurder zelf in alle vrijheid moet kunnen bijdragen aan besluitvorming en zich hierbij bijvoorbeeld niet enkel mag laten leiden door de wensen van de aandeelhouders. Hierbij is van belang dat in het tweede lid van dit artikel bepaald is dat deze gedragsnorm niet geschonden wordt in het geval dat een bestuurder handelt in overeenstemming met een overeenkomst met de rechtspersoon die zijn bevoegdheden beperkt of een beperking die voortvloeit uit de statuten van de rechtspersoon.

\subsection{Duty to exercise reasonable care, skill and diligence} (art. 174)

Op grond van artikel 174 CA 2006 dient een bestuurder zorg, bekwaamheid en zorgvuldigheid te betrachten bij de uitoefening van zijn taken. Hierbij wordt uitgegaan van de zorg, bekwaamheid en zorgvuldigheid die kunnen worden verwacht van een redelijk denkend persoon met (1) de algemene kennis, bekwaamheid en ervaring die redelijkerwijs kunnen worden verwacht van een persoon in de functie van bestuurder, en (2) de algemene kennis, bekwaamheid en ervaring van de bestuurder zelf.

\subsection{Duty to avoid conflicts of interest (art. 175)}

De vijfde algemene gedragsnorm is de plicht voor een bestuurder om een (eventueel) tegenstrijdig belang met de rechtspersoon te voorkomen. Het gaat hierbij om de situatie dat de bestuurder een direct of indirect belang heeft of kan hebben, dat in conflict is met de belangen van de rechtspersoon. Dit ziet in het bijzonder op het exploiteren van enig goed, informatie of (corporate) opportunity.

\subsection{Duty not to accept benefits from third parties (art. 176)}

Op grond van artikel 176 CA 2006 mag een bestuurder geen persoonlijk voordeel van een derde verkrijgen enkel voor het feit dat hij bestuurder is, of omdat hij in zijn hoedanigheid van bestuurder iets doet of niet doet.

\subsection{Duty to declare interest in proposed transaction or arrangement (art. 177)}

De plicht van artikel 177 CA 2006 houdt in dat een bestuurder, wanneer hij een direct of indirect persoonlijk belang heeft bij een voorgenomen transactie of overeenkomst met de rechtspersoon, de aard en omvang van zijn belang aan de andere bestuurders moet meedelen.

\section{Vergelijking van gedragsnormen}

Uit de vorige paragrafen blijkt dat zowel in Nederland als in het Verenigd Koninkrijk gedragsnormen gelden voor bestuurders van rechtspersonen. In de Nederlandse literatuur en

26. Zie hierover M.M. Parkinson, Director's duty to exercise independent judgment: The path to s. 173 of the Companies Act 2006 and beyond, Company Lawyer (38) 2017, afl. 9, p. 271-277. 


\section{Maandblad \\ Ondernemingsrecht}

rechtspraak worden twee algemene plichten voor bestuurders onderscheiden. Dit zijn: (1) een plicht tot loyaal handelen en (2) een plicht tot zorgvuldig handelen. Deze gedragsnormen zijn echter niet als zodanig wettelijk verankerd. De CA 2006 kent daarentegen wel een aantal gecodificeerde algemene plichten (of normen) voor bestuurders. In deze paragraaf zal worden besproken in hoeverre de gedragsnormen die in het Verenigd Koninkrijk gelden, ook in Nederland kunnen worden waargenomen.

\subsection{Duty to act within powers}

Deze eerste plicht houdt in dat een bestuurder binnen zijn bevoegdheden moet handelen, waarbij de bevoegdheden van het bestuur voortvloeien uit de wet en de statuten van de desbetreffende rechtspersoon. Ook in Nederland is de ondernemer in beginsel verplicht om conform de wet en de statuten te handelen. In het Berghuizer Papierfabriek-arrest heeft de Hoge Raad overwogen dat het handelen van een bestuurder in strijd met een statutaire bepaling die de rechtspersoon beoogt te beschermen in beginsel een 'ernstig verwijt' oplevert. De bestuurder is in dit geval aansprakelijk, tenzij uit feiten en omstandigheden anders blijkt. ${ }^{27}$ Aangenomen wordt dat deze regel ook geldt voor schending van wettelijke regels die de rechtspersoon beogen te beschermen. ${ }^{28}$

Voorts valt onder deze plicht ook het verbod om een bevoegdheid te gebruiken voor een ander doel dan waarvoor deze is verleend. In Nederland is dit beginsel bekend van het bestuursrecht: overheidsbevoegdheden mogen uitsluitend worden gebruikt ten behoeve van het algemeen belang (en dus niet voor persoonlijke motieven) en voor die specifieke doeleinden die de wetgever voor ogen had bij het verlenen van die bevoegdheid. ${ }^{29}$ Binnen het vermogensrecht is dit beginsel neergelegd in het tweede lid van artikel 3:13 BW. Dit geldt op grond van artikel 3:15 BW ook in het rechtspersonenrecht. In dit artikel is bepaald dat sprake kan zijn van misbruik van bevoegdheid indien een bevoegdheid gebruikt wordt met een ander doel dan waarvoor zij is verleend. Binnen het ondernemingsrecht wordt artikel 3:13 BW evenwel niet of nauwelijks toegepast, veelal wordt in dergelijke situaties een beroep gedaan op artikel 2:8 lid $2 \mathrm{BW}$. Op grond van deze bepaling is een krachtens wet, gewoonte, statuten, reglementen of besluit geldende regel niet van toepassing voor zover dit in de gegeven omstandigheden naar maatstaven van redelijkheid en billijkheid onaanvaardbaar zou zijn.

\subsection{Duty to promote the success of the company}

De tweede plicht uit de CA 2006 houdt in dat het de plicht van een bestuurder is om het succes van het bedrijf te bevorderen ten behoeve van zijn aandeelhouders als geheel. Een

27. HR 29 november 2002, ECLI:NL:HR:2002:AE7011 (Berghuizer Papierfabriek).

28. Zie M.J. Kroeze, L. Timmerman \& J.B. Wezeman, De kern van het ondernemingsrecht, Deventer: Wolters Kluwer 2017, p. 138.

29. Art. 3:3 Awb. Zie ook H.D. Tolsma, Commentaar op Algemene wet bestuursrecht, art. 3:13, in: K.J. de Graaf e.a. (red.), Sdu Commentaar Algemene wet bestuursrecht 2016, Den Haag: Sdu Uitgevers 2016. bestuurder moet hierbij rekening houden met andere belangen. Een aantal van die belangen is in de wet gespecificeerd. Er geldt aldus een verplichting om met andere belangen dan die van aandeelhouders rekening te houden, maar die andere belangen hebben in beginsel minder zelfstandige betekenis dan het aandeelhoudersbelang.

In Nederland kennen we - met inachtneming van het Nederlandse stakeholdersperspectief - het bepaalde in artikel 2:129/239 lid 5 BW:

'Bij de vervulling van hun taak richten de bestuurders zich naar het belang van de vennootschap en de met haar verbonden onderneming. ${ }^{30}$

In de parlementaire geschiedenis valt hierover te lezen:

'In een NV/BV komen de belangen van kapitaalverschaffers, werknemers, crediteuren en andere contractspartijen samen. Het bestuur en de raad van commissarissen van een $\mathrm{NV} / \mathrm{BV}$ hebben op grond van de wet de opdracht om zich te richten naar het belang van de vennootschap en de daarmee verbonden onderneming. $\mathrm{Zij}$ moeten de hiervoor bedoelde verschillende belangen behoorlijk afwegen bij de vervulling van hun taak. In de regel moeten zij zich richten op de continuïteit van de onderneming voor de langere termijn. Het voortbestaan van ondernemingen is van groot belang voor de werkgelegenheid en het behoud van inkomen van de Nederlandse beroepsbevolking. In meer brede zin is een goed en verantwoord bestuur van ondernemingen ook van groot belang voor het welzijn van burgers en instellingen, bijvoorbeeld omdat zij in ondernemingen beleggen of doordat ondernemingsactiviteiten invloed hebben op het leefmilieu. 31

De Hoge Raad oordeelde voorts in het ABN AMRO-arrest als volgt:

'(...) dat het bestuur bij de vervulling van zijn bij wet of statuten opgedragen taken het belang van de vennootschap en de daaraan verbonden onderneming behoort voorop te stellen en de belangen van alle betrokkenen, waaronder die van de aandeelhouders, bij zijn besluitvorming in aanmerking behoort te nemen.' 32

In de recente uitspraak inzake Elliott/AkzoNobel noemt de Ondernemingskamer de twee bekende basisnormen die wij in Nederland kennen, te weten: (1) het bestuur moet rekening houden met het belang van de vennootschap en de met haar verbonden onderneming, welk belang vooral bepaald wordt

30. Zie ook art. 2:140/250 lid 2 BW.

31. Nota naar aanleiding van het verslag bij het (destijds) wetsvoorstel Wijziging van boek 2 van het Burgerlijk Wetboek in verband met de aanpassing van regels over bestuur en toezicht in naamloze en besloten vennootschappen. Zie Kamerstukken II 2008/09, 31763, 6, p. 1-2.

32. HR 13 juli 2007, ECLI:NL:HR:2007:BA7972 (ABN AMRO), r.o. 4.5. 
door het bevorderen van het bestendige succes van deze onderneming; en (2) het bestuur moet mede op grond van het bepaalde in artikel 2:8 BW zorgvuldigheid betrachten met betrekking tot de belangen van al degenen die bij de vennootschap en haar onderneming zijn betrokken. ${ }^{33}$ In Cancun had de Hoge Raad eerder overwogen dat het vennootschapsbelang in de regel vooral bepaald wordt door het bevorderen van het bestendige succes van deze onderneming. ${ }^{34}$ In Elliott/AkzoNobel overwoog de Ondernemingskamer voorts dat het bestuur van een doelvennootschap zich bij de beoordeling van voorstellen van een potentiële bieder, onder toezicht van de raad van commissarissen, dient te richten op de langetermijnwaardecreatie van de vennootschap en de met haar verbonden onderneming, en daartoe de in aanmerking komende belangen van de stakeholders dient te wegen. ${ }^{35}$ Het bestuur moet de diverse deelbelangen afwegen en derhalve mag het belang van de aandeelhouders niet automatisch voorop worden gesteld. ${ }^{36}$ Aldus kan worden geconcludeerd dat het vennootschapsbelang in Nederland als uitgangspunt niet samenvalt met het belang van de aandeelhouder(s). Ten slotte wijzen wij erop dat een voordeel van de benadering in het Verenigd Koninkrijk is dat het bestuurders meer dan de huidige vrije Nederlandse benadering dwingt om toe te lichten waarom zij tot een bepaalde belangenafweging zijn gekomen.

\subsection{Duty to exercise independent judgment}

De derde verplichting uit de CA 2006 houdt in dat het bestuur in alle vrijheid tot een besluit moet kunnen komen. Ook binnen het Nederlands rechtspersonenrecht geldt het beginsel van bestuursautonomie: aan het bestuur komen, binnen de grenzen van zijn door de wet en de statuten aangegeven taak, zelfstandigheid en beleidsvrijheid toe. Dit vloeit onder meer voort uit het Forumbank-arrest van de Hoge Raad, waarin als volgt bepaald is:

'dat in deze stelling, aldus verstaan, echter wordt voorbijgezien dat ook de algemene vergadering de bij wet en statuten getrokken grenzen harer bevoegdheid niet mag overschrijden en dat het Hof, in cassatie onbestreden, als voormeld heeft vastgesteld dat de inkoop van eigen aandelen uitsluitend tot de bevoegdheid van de directie behoort'. ${ }^{37}$

De algemene vergadering gaat ook in beginsel niet over het voorbereiden, vaststellen en uitvoeren van het beleid en de strategie van de vennootschap. ${ }^{38}$ Op grond van artikel 2:129/239 lid 4 BW kunnen de statuten echter wel voorzien in een bindend instructierecht voor de algemene vergadering.

33. Hof Amsterdam (OK) 29 mei 2017, ECLI:NL:GHAMS:2017:1965.

34. Zie HR 4 april 2014, ECLI:NL:HR:2014:799 (Cancun), r.o. 4.2.1.

35. Hof Amsterdam (OK) 29 mei 2017, ECLI:NL:GHAMS:2017:1965.

36. Kamerstukken II 2008/09, 31763, 6, p. 9. Zie ook B.F. Assink, Kanttekeningen bij Boskalis/Fugro, MvO 2018, afl. 7, p. 183-197.

37. HR 21 januari 1955, NJ 1959/43.

38. Zie onder meer HR 9 juli 2010, ECLI:NL:HR:2010:BM0976 (ASMI); HR 13 juli 2007, ECLI:NL:HR:2007:BA7972 (ABN AMRO); Hof Amsterdam (OK) 17 januari 2007, ECLI:NL:GHAMS:2007:AZ6440 (Stork)
In het geval van een naamloze vennootschap mogen dit slechts instructies over algemene lijnen betreffen. Bij een besloten vennootschap kan in de statuten worden opgenomen dat het bestuur zich dient te gedragen naar de aanwijzingen van de algemene vergadering, waarbij de algemene vergadering concrete instructies mag geven. Deze beperking is in lijn met artikel 173 CA 2006, waar in het tweede lid is bepaald dat deze gedragsnorm niet geschonden wordt ingeval een bestuurder handelt in overeenstemming met een overeenkomst met de rechtspersoon die zijn bevoegdheden beperkt of een beperking die voortvloeit uit de statuten van de rechtspersoon.

\subsection{Duty to exercise reasonable care, skill and diligence}

De vierde plicht uit de CA 2006 houdt in dat een bestuurder redelijke zorg, bekwaamheid en zorgvuldigheid moet betrachten bij de uitoefening van zijn taken. In Nederland is een bestuurder op grond van artikel 2:9 BW verplicht tot een behoorlijke vervulling van zijn taak. De term 'behoorlijke taakvervulling' brengt met zich mee dat een bestuurder moet handelen met de gepaste zorg, bekwaamheid en zorgvuldigheid. In het Staleman/Van de Ven-arrest overwoog de Hoge Raad dat bij de beoordeling of er sprake is van een ernstig verwijt, mede gekeken moet worden naar 'het inzicht en de zorgvuldigheid die mogen worden verwacht van een bestuurder die voor zijn taak berekend is en deze nauwgezet vervult'. Van een bestuurder wordt dus verwacht dat hij de daarvoor vereiste capaciteiten bezit. Met andere woorden: een bestuurder moet zowel de kennis als de kunde hebben die van iemand in zijn positie binnen de desbetreffende rechtspersoon in redelijkheid kan worden verwacht.

Voorts heeft een bestuurder in Nederland een zorgplicht jegens de rechtspersoon. Deze zorgplicht kan zowel actief (handelen) als passief (nalaten) zijn. ${ }^{39}$ Op grond van deze zorgplicht is een bestuurder onder andere verplicht om een besluit te maken op een geïnformeerde en doordachte wijze. ${ }^{40}$ Een bestuurder moet zich dus tijdig voorzien van alle informatie die redelijkerwijs voorhanden en noodzakelijk is om tot besluitvorming te komen. Hieronder valt ons inziens ook het vragen van advies, goedkeuring of instemming aan organen binnen de rechtspersoon. Vervolgens moet de bestuurder deze informatie grondig doornemen om op een doordachte wijze het besluit te kunnen maken. Het nemen van beslissingen met verregaande consequenties zonder deugdelijke voorbereiding kan namelijk tot een 'ernstig verwijt' leiden. ${ }^{41}$

\subsection{Duty to avoid conflicts of interest}

De vijfde algemene plicht uit de CA 2006 houdt in dat een bestuurder een (eventueel) tegenstrijdig belang met de rechts-

39. Op basis van art. 2:9 lid 2 BW draagt iedere bestuurder verantwoordelijkheid voor 'de algemene gang van zaken'. In de parlementaire geschiedenis wordt helaas niet verduidelijkt wat onder 'de algemene gang van zaken' valt, waardoor onduidelijk is wat hier nu precies onder valt.

40. Assink/Slagter 2013, \$51.

41. D.A.M.H.W. Strik, Commentaar ondernemingsrecht, art. 9, in: B. Bier e.a. (red.), Sdu Commentaar ondernemingsrecht 2015-2016, Den Haag: Sdu Uitgevers 2015. 


\section{Maandblad \\ Ondernemingsrecht}

persoon moet proberen te voorkomen. Het Nederlands vennootschapsrecht kent ook een tegenstrijdig-belangregeling. ${ }^{42}$ Deze is te vinden in artikel 2:129/239 lid 6 BW. Deze bepaling komt erop neer dat een bestuurder niet deelneemt aan de beraadslaging en besluitvorming indien hij daarbij een direct of indirect persoonlijk belang heeft dat tegenstrijdig is met het belang van de vennootschap en de met haar verbonden onderneming.

Of sprake is van een tegenstrijdig belang dient te worden beantwoord met inachtneming van alle relevante omstandigheden van het concrete geval. ${ }^{43}$ Er geldt een materiële benadering van het begrip tegenstrijdig belang. De enkele mogelijkheid van een tegenstrijdig belang zonder dat dit wordt geconcretiseerd is onvoldoende. De strekking is om de bestuurder bevoegdheid te ontzeggen als hij door de aanwezigheid van een persoonlijk belang of door zijn betrokkenheid bij een ander met dat van de rechtspersoon niet parallel lopend belang niet in staat moet worden geacht het belang van de vennootschap en de daaraan verbonden onderneming te bewaken op een wijze die van een integer en onbevooroordeeld bestuurder mag worden verwacht. Of er daadwerkelijk benadeling optreedt, is niet doorslaggevend. Voldoende is dat de bestuurder te maken heeft met zodanig onverenigbare belangen, dat in redelijkheid kan worden betwijfeld of hij zich bij zijn handelen uitsluitend heeft laten leiden door het belang van de vennootschap en de daaraan verbonden onderneming. Een zuiver kwalitatief tegenstrijdig belang - het 'dragen van twee petten' door de bestuurder - levert geen tegenstrijdig belang in de zin van artikel 2:239 lid 6 BW. In de statuten zou voor de toepassing van artikel 2:239 lid 6 BW een nadere concretisering kunnen worden opgenomen van situaties waarbij er wel of geen tegenstrijdig belang bestaat. Ruimere omschrijvingen lijken ook mogelijk. Een dergelijke vaststelling is evenwel niet bindend voor de toepassing van artikel 2:239 lid 6 BW. Dit omdat de rechter uiteindelijk bepaalt wanneer sprake is van een dergelijk tegenstrijdig belang. Een schending van deze regeling zal in beginsel leiden tot de aansprakelijkheid van het bestuur. Het betreft hier namelijk een wettelijke bepaling die de rechtspersoon beoogt te beschermen. Op grond van het reeds aangehaalde Berghuizer Papierfabriek-arrest levert zo'n schending in beginsel een 'ernstig verwijt' op. Het is in de praktijk door het ontbreken van een wettelijke definitie van het begrip tegenstrijdig belang nogal eens onzeker of de regeling van artikel 2:129/239 lid 6 BW moet worden toegepast. Het is de vraag of de praktijk niet iets meer vrijheid kan worden gegeven om tegenstrijdig belang nader te definiëren in statuten of codes. $^{44}$

42. Na de aanname en inwerkingtreding van het wetsvoorstel Bestuur en toezicht rechtspersonen zal er een tegenstrijdig-belangregeling voor alle Boek $2 \mathrm{BW}$-rechtspersonen gelden.

43. HR 29 juni 2007, NJ 2007/420 (Bruil).

44. Zie voor een dergelijk pleidooi A.F.M. Dorresteijn, Wetsvoorstel 34 491: 'Bruil-vrij' tegenstrijdig belang, WPNR 2018/7188.
De 'duty to avoid conflicts of interest' in het Verenigd Koninkrijk omvat ook corporate opportunity's. Van corporate opportunity's is sprake als een bestuurder zakelijke kansen die aan de rechtspersoon toekomen, benut voor zichzelf of een van zijn naasten. Artikel 2:129/239 lid 6 BW ziet niet op corporate opportunity's, omdat doorgaans geen bestuursbesluit ter zake wordt genomen. Bestuurders die corporate opportunity's (laten) benutten, kunnen onder omstandigheden persoonlijk aansprakelijk worden gesteld wegens onbehoorlijke taakvervulling. ${ }^{45}$

\subsection{Duty not to accept benefits from third parties}

Op grond van artikel 176 CA 2006 mag een bestuurder geen persoonlijk voordeel van een derde verkrijgen enkel voor het feit dat hij bestuurder is, of omdat hij in zijn hoedanigheid als bestuurder iets doet of niet doet. Met de bepaling is met name beoogd om 'secret profits and bribery' tegen te gaan. ${ }^{46} \mathrm{Het}$ Nederlands recht kent geen vergelijkbare bepaling. Dat neemt niet weg dat doorgaans dergelijk gedrag wel zal worden gekwalificeerd als onbehoorlijke takkvervulling (art. 2:9 BW).

\subsection{Duty to declare interest in proposed transaction or arrangement}

Op grond van artikel 177 CA 2006 moet een bestuurder tijdig bekendmaken dat hij een direct of indirect persoonlijk belang heeft bij een transactie of overeenkomst van de rechtspersoon. Deze verplichting houdt dus verband met die van artikel 175 CA 2006. Ook op grond van de Nederlandse tegenstrijdigbelangregeling moet een bestuurder die een direct of indirect persoonlijk belang heeft dat tegenstrijdig is met het belang van de vennootschap, dit melden aan zijn medebestuurders. ${ }^{47}$

In het onlangs ter consultatie aangeboden conceptwetsvoorstel ter omzetting van de aanpassingen van de aandeelhoudersrichtlijn is er onder de noemer 'related party transactions' ook aandacht voor dit onderwerp. ${ }^{48}$ Dergelijke transacties moeten worden goedgekeurd door de algemene vergadering, de raad van commissarissen of de niet-uitvoerende bestuurders in het bestuur, waarbij de geconflicteerde in beginsel geen stemrecht toekomt.

45. Zie Rb. Midden-Nederland 19 februari 2014, ECLI:NL:RBMNE 2014:457: 'Indien de bestuurder een corporate opportunity aanwendt ten behoeve van zichzelf of van derden, zonder dat de vennootschap deze opportunity heeft vrijgegeven, dan schiet hij tekort in de uitoefening van de hem opgedragen taak. Kan de bestuurder daarvan een ernstig verwijt worden gemaakt, dan is hij jegens de vennootschap voor diens schade aansprakelijk op grond van artikel 2:9 BW. Van een ernstig verwijt is in beginsel sprake indien de bestuurder zijn eigen belang laat prevaleren boven dat van de vennootschap.'

46. A. Keay \& L. Kosmin, Directors' duties, Bristol: Jordans 2009, p. 303.

47. Kamerstukken II 2008/09, 31763, 6, p. 21.

48. Richtlijn 2017/828 van het Europees Parlement en de Raad van 17 mei 2017 tot wijziging van Richtlijn 2007/36/EG wat het bevorderen van de langetermijnbetrokkenheid van aandeelhouders betreft. 


\section{Is codificatie van gedragsnormen in Boek $2 \mathrm{BW}$ wenselijk?}

In de vorige paragraaf is geanalyseerd in welke mate de zeven gedragsnormen uit de CA 2006 in het Nederlands rechtspersonenrecht terug te vinden zijn. Uit deze analyse kan worden geconcludeerd dat deze plichten ook in het Nederlands rechtspersonenrecht voorkomen. Wel is sprake van een versnipperd en ongestructureerd leerstuk, hetgeen de kenbaarheid en voorspelbaarheid niet ten goede komt. ${ }^{49}$ Sommige plichten zijn - al dan niet specifiek - wettelijk geregeld, andere volgen uit de jurisprudentie en weer andere vallen onder de werking van behoorlijk bestuur van artikel 2:9 BW. Voorstelbaar is dat het voor de meeste bestuurders niet eenvoudig zal zijn om dit ongeordende stelsel van gedragsnormen te overzien. Uit een casestudie van Pham uit 2015 blijkt dat bestuurders een hoge mate van aansprakelijkheidsrisico's ervaren, waarbij de meerderheid van de geïnterviewden het aansprakelijkheidsrisico overschat. ${ }^{50}$ Bestuurders zijn bang voor aansprakelijkheden en reputatieverlies. ${ }^{51}$ Deze angst kan leiden tot defensief gedrag onder bestuurders, waardoor ze sneller zullen afzien van risicovolle, maar potentieel winstgevende beslissingen. Een codificatie van de algemene gedragsnormen voor bestuurders kan deze onzekerheid en onduidelijkheid naar onze mening doen afnemen. ${ }^{52}$ Reeds in 1990 heeft Van Leeuwen in haar proefschrift een poging gewaagd om bestuurders meer houvast te bieden door het formuleren van diverse beginselen van behoorlijk

49. Zie ook B.F. Assink, Een Nederlandse business judgment rule in de context van het enquêterecht en bestuurdersaansprakelijkheid ex art. 2:9 BW: quo vadis?, Ondernemingsrecht 2013/50, p. 255 en 256.

50. Pham merkt wel op dat bestuurders die tevens eigenaar, (mede)oprichter of controlerende aandeelhouder waren, de aansprakeliikheidsrisico's onderschatten. N.T. Pham, Bange bestuurders? Een casestudie onder Nederlandse top-level bestuurders, in: B.F. Assink e.a. (red.), De toekomst van het ondernemingsrecht. Het ondernemingsrecht van de toekomst (IVOR nr. 99), Deventer: Wolters Kluwer 2015, p. 411-434.

51. Zie ook C.A. Schwarz, Hoeveel goeds en groots blijft er niet achterwege uit angst voor de verantwoordelijkheid?, in: De vele gezichten van Maarten Kroeze's 'bange bestuurders', Deventer: Wolters Kluwer 2017, p. 147-155. Hierin stelt Schwarz dat de laatste decennia sprake is van een afname van angstgevoelens en onzekerheid die worden veroorzaakt door matige kennis van de complexe aansprakelijkheidsregelingen.

52. Dit is in de kern ook het effect van de norm voor uitkeringen die in art. 2:216 BW is gecodificeerd. Stokkermans schreef hierover: 'Codificatie van de aansprakelijkheidsnorm makt de norm beter zichtbaar. Het bestuur wordt met de neus op zijn verantwoordelijkheden gedrukt. Hiervan kan een preventieve werking uitgaan.' Zie Chr.M. Stokkermans, Verantwoorde uitkeringen, WPNR 2012/6933. ondernemingsbestuur. ${ }^{53}$ Het betrof een lijst met beginselen, ${ }^{54}$ waarbij volgens Dorresteijn eigenlijk niet gesproken kon worden van beginselen, omdat er geen sprake was van 'onmiddellijke evidentie' en 'kennelijke geldigheid'. 55 Onze voorkeur gaat niet uit naar wat meer 'vage' beginselen, maar naar een lijst van meer concrete, specifieke gedragsnormen. Sommige van de beginselen van Van Leeuwen zijn overigens vrij concrete, specifieke gedragsnormen. Een codificatie van gedragsnormen, op soortgelijke wijze als in de CA 2006, lijkt ons een nuttige ontwikkeling voor het Nederlands ondernemingsrecht. Een dergelijke codificatie zou kunnen worden vormgegeven door het bij elkaar plaatsen van een aantal specifieke gedragsnormen in een wetsartikel in de eerste titel van Boek 2 BW. Wel merken wij op dat er meer gedragsnormen zijn dan die in het Verenigd Koninkrijk zijn gecodificeerd in de artikelen 171-177 CA $2006 .{ }^{56}$ Daarnaast is de strekking van ons artikel niet om te verdedigen dat exact dezelfde gedragsnormen die in het Verenigd Koninkrijk zijn gecodificeerd in de artikelen 171-177 CA 2006 ook in Nederland overgenomen zouden moeten worden. De strekking is dat ons inziens bestuurders in de praktijk gebaat zijn bij codificatie van gedragsnormen en het bij elkaar plaatsen van deze normen, opdat een helder en overzichtelijk kader ontstaat, conform de strekking van de aanpassingen in het Verenigd Koninkrijk in 2006. In deze bijdrage onthouden wij ons overigens van het doen van een voorstel voor de exacte invulling en bewoordingen van deze gedragsnormen. Over de vraag welke gedragsnormen gecodificeerd kunnen worden, is veel discussie mogelijk en valt ook veel te zeggen. Dat gaat de omvang van dit artikel te buiten. Met dit artikel pogen wij vooral aandacht te vragen voor dit vraagstuk, omdat het ons inziens belangrijk is dat deze discussie gevoerd wordt.

\section{Afsluiting}

In deze bijdrage hebben wij ons gericht op de gedragsnormen die gelden voor bestuurders van rechtspersonen en hebben wij

53. Deze beginselen van behoorlijk bestuur zijn: het bestuur moet bij de bepaling van het ondernemingsbelang de relevante belangen afwegen (willekeursverbod); het bestuur moet zich houden aan de wet, de openbare orde en goede zeden, de statuten en reglementen; het bestuur mag zijn bevoegdheid niet voor een ander doel gebruiken dan waarvoor deze is gegeven (zuiverheid van oogmerk); besluiten van het bestuur dienen zorgvuldig te worden voorbereid (zorgvuldigheidsbeginsel); het bestuur dient zich te verantwoorden (verantwoordingsbeginsel); een opgewekt vertrouwen moet in beginsel worden gehonoreerd (vertrouwensbeginsel); gelijke gevallen moeten gelijk worden behandeld (gelijkheidsbeginsel); het bestuur dient greep te hebben op de organisatie van de onderneming; en het bestuur dient te zorgen voor continuïteit in de bezetting van belangrijke functies in de onderneming. Zie B.H.A. van Leeuwen, Beginselen van behoorlijk ondernemingsbestuur; een onderzoek naar de juridische normering van het besturen van een onderneming, Deventer: Kluwer 1990 .

54. Zie hierover ook Timmerman, die de voorkeur gaf aan twee beginselen, namelijk de duty of care en de duty of loyalty. Zie L. Timmerman, Enkele opmerkingen over normering van het handelen van de bestuurders van n.v.'s en b.v.'s, TVVS 1992, afl. 2, p. 31-35.

55. A.F.M. Dorresteijn, Boekbespreking: Zijn er beginselen van behoorlijk ondernemingsbestuur?, WPNR 1991/5997, p. 176.

56. Zo zou kunnen worden gedacht aan respect voor mensenrechten, milieu en veiligheid. 


\section{Maandblad}

Ondernemingsrecht

geanalyseerd in welke mate de directors' duties uit de CA 2006 ook in Nederland voorkomen. Uit onze analyse volgt dat deze gedragsnormen ook in het Nederlands recht voorkomen. Wel is gebleken dat sprake is van een versnipperd en ongestructureerd leerstuk, hetgeen de kenbaarheid en voorspelbaarheid van deze gedragsnormen niet ten goede komt. Een codificatie van algemene gedragsnormen voor bestuurders kan deze onzekerheid en onduidelijkheid naar onze mening doen afnemen. Een codificatie van gedragsnormen, op soortgelijke wijze als in de CA 2006, lijkt daarom een nuttige ontwikkeling voor het Nederlands ondernemingsrecht. Wij denken dat bestuurders in de praktijk hierbij gebaat zijn. 